\title{
Analyse écophysiologique des effets de stress liés aux transplantations des arbres forestiers
}

\author{
P. KAUSHAL ${ }^{(*)}$
}

Les études ont été faites au Centre de Recherche forestière, I.N.R.A., Nancy, France, sur des semis de Cedrus atlantica Manetti et Pinus nigra ssp. laricio Poiret var. Corsicana âgés de 9 mois à 3 ans.

Les relations hydriques, la régénération racinaire, la photosynthèse, la transpiration, la croissance aérienne et la survie des plantes ont été étudiées pour des plants transplantés ayant eu une irrigation régulière, ou ayant été prétraités par une sécheresse.

Les semis transplantés en conteneurs ont commencé à reprendre leurs fonctions physiologiques normales après 6-7 semaines de transplantation mais les semis transplantés en pépinière ont eu un stress hydrique qui a duré au moins 190 jours. La régénération racinaire ne se manifeste pas au-delà d'un seuil de potentiel hydrique de - 1,7 MPa chez le Cèdre, alors que ce seuil a été de - 1,5 MPa pour le Pin laricio.

Les semis ayant subi une sécheressse ont régénéré leurs racines à un plus faible potentiel hydrique $(-2,8 \mathrm{MPa}$ pour le Cèdre ; - 1,6 MPa pour le Pin laricio). La régénération racinaire a été aussi plus élevée chez le semis ayant subi une sécheresse.

La fertilisation azotée au moment de la transplantation a maintenu un taux de photosynthèse élevé entre la transplantation et la régénération racinaire. La reprise de la photosynthèse a eu lieu après le démarrage de la croissance racinaire et le taux de photosynthèse pour le Cèdre est corrélé positivement avec le nombre des racines blanches régénérées. La photosynthèse et la transpiration ont été significativement plus faibles pour les plants transplantés que pour les plants témoins non arrachés, même 216 jours après transplantation.

La croissance aérienne l’année suivant la transplantation a été moins importante chez les plants transplantés.

Les réserves glucidiques ont été évaluées avant et après transplantation chez les plants irrigués régulièrement et chez les plants prétraités par une sécheresse. L'application d'une sécheresse a réduit le taux d'amidon dans les racines et dans les aiguilles. La teneur en amidon a été faible même 190 jours après transplantation. La variation saisonnière a été aussi étudiée pour le Pin laricio. La concentration des sucres en avril a été significativement plus élevée que celle d'octobre.

Des semis âgés de 10 mois ont été aussi élevés pendant une saison de végétation dans des atmosphères à teneur en $\mathrm{CO}_{2}$ différentes $(350$ et $800 \mathrm{vpm})$. La concentration la plus élevée a augmenté la matière sèche des plants de 66 et $30 \mathrm{p}$. 100 respectivement pour le Cèdre et le Pin laricio. La répartition de la biomasse entre les parties aérienne et souterraine n'a pas été affectée. Les croissances en hauteur et en diamètre ont été augmentées de 20 p. 100 pour le Cèdre et de 10-14 p. 100 pour le Pin laricio.

Mots clés : Semis, transplantation, relations hydriques, habillage des racines, fertilisation azotée, sécheresse, photosynthèse, transpiration, réserves glucidiques, régénération racinaire, Cedrus atlantica, Pinus nigra, enrichissement en $\mathrm{CO}_{2}$.

$\left(^{*}\right)$ Station de Sylviculture et de Production, I.N.R.A. Champenoux, 54280 Seichamps, et ProfesseurAssistant en foresterie à l'Université d'Agriculture du Pendjab, Inde. Thèse soutenue le 26 septembre 1987 à l'Université de Nancy I (U.E.R. Physique-Chimie-Biologie). 


\section{Summary \\ Ecophysiological analysis of transplanting stress effects in forest trees}

The studies were carried out on young seedlings (9-36 months) of Cedrus atlantica Manetti and Pinus nigra Arn. ssp. laricio Poiret var. Corsicana at the Forestry Research Center, I.N.R.A, Nancy, France.

Water relations, root regeneration, photosynthesis, transpiration, shoot growth and survival were studied in the transplants either regularly irrigated or preconditioned by drought before planting.

Container transplanted seedlings recovered after 6-7 weeks where as field transplanted scedlings remained water stressed for a minimum period of 190 days. Root regeneration did not occur below a predawn xylem water potential of $-1,7 \mathrm{MPa}$ in cedar and $-1,5 \mathrm{MPa}$ in pine.

Drought subjected seedlings did regenerate at still lower xylem water potential $(-2,8 \mathrm{MPa}$ for cedar ; - 1,6 MPa for laricio pine). Root regeneration was high in the seedlings which received drought treatment before planting.

Nitrogen fertilisation at planting maintained higher level of photosynthesis in the transplants during the period between transplanting and root regeneration. Pruning of white root tips at the time of planting increased the new root production. Recovery of photosynthesis in transplants took place only after the root regeneration and rate of photosynthesis in cedar was positively correlated to the number of white roots produced. Photosynthesis and transpiration was significantly low in the field transplanted seedlings than the intact ones even after 216 days of transplanting.

First season terminal shoot growth was significantly reduced in the transplants.

Carbohydrate reserves were evaluated before and after planting both in the regularly irrigated and drought preconditioned seedlings. Drought treatment reduced the starch contents in leaves and roots. Starch contents observed after 190 days of transplanting were low in the transplanted seedlings. Seasonal variation has also been studied in laricio pine and carbohydrate concentrations in April were significantly higher than in October.

In an another experiment 10 months old seedlings were grown in two levels of $\mathrm{CO}_{2}$ concentrations of $350 \mathrm{vpm}$ and $800 \mathrm{vpm}$ for 9 months. Elevated concentrations increased total dry weight by 66 and 30 p. 100 respectively in cedar and laricio pine but the biomass partitioning remain unaffected. Increase in height and diametre was $20 \mathrm{p} .100$ for cedar and $10-14 \mathrm{p} .100$ for laricio pine.

Key words: Seedlings, transplanting, water stress, root pruning, nitrogen fertilisation, drought, photosynthesis, transpiration, carbohydrate reserves, root regeneration, $\mathrm{CO}_{2}$ enrichment, Cedrus atlantica, Pinus nigra. 